\title{
12 New approaches in the Renaissance
}

From the scientific point of view the Renaissance was not a renaissance.

Sarton (1929: 76)

\$1 The term 'Renaissance', intended as a rebirth of Antiquity, was first used in art, although as late as the mid-sixteenth century, by Giorgio Vasari. ${ }^{1}$ Moreover, it was only Jacob Burckhardt's epoch-making work Die Cultur der Renaissance in Italien (1860) that paved the way for the introduction of a completely new epoch in all facets of life emerging in fifteenth-century Italy, one that tried to renew and emulate Roman Antiquity. His approach has been much criticised in the past few decades; indeed, even the fact that many leading Renaissance men were members of the clergy should have alerted scholars to the fact that they did not intend to resurrect ancient Rome in all its facets, which would have included pagan religion. Even so, it does still make sense to have a new epoch begin in fifteenth century, as in this time many external parameters changed that were bound to influence people's perception of themselves and their relation to the past. The most important of these were the immigration of Greeks to Italy (in 1453 Constantinople fell to the Ottomans); the invention of the printing press (Gutenberg from 1455), ${ }^{2}$ accelerating the circulation of new ideas decidedly; the new republican state forms in Italy, in which a new, flourishing literate middle class engaged in trade; and, in connection with this knowledge of foreign places, the reconquista of the Iberian peninsula (completed in 1492). This led to the age of discoveries: Bartolomeu Dias sailed around Africa in 1488, Columbus landed in the New World in 1492, Vasco da Gama reached India in 1498, and Fernão de Magalhães, finally, sailed around the world in $1522 .{ }^{3}$

The term 'Renaissance humanism' is used in order to emphasise the new picture of man emerging in this time. ${ }^{4}$ This entailed the possibility of forming man to true humanity by means of classical studies (and, in contrast to earlier similar attempts, outside the Church). Humanism was at its core a rhetorical and pedagogical movement, seeking to move away from 'un-Latin' and unrhetorical scholastic language and back to Ciceronian purity of language and thought. Many humanists were themselves teachers or wrote textbooks and translations intended to supplant the 'barbarous', 'mediaeval' material available. A high appreciation of Greek culture came as a by-product of emulating classical Roman erudition. The

1 See $O E D$ (s.v. 'renaissance').

2 See Eisenstein (1979); White (2017).

3 More on these matters in chap. $13 \S 3$.

4 For this topic, see Kristeller (1961).

Ә Open Access. () 2021 Philipp Roelli, published by De Gruyter. (c) BY Creative Commons Attribution 4.0 International License.

https://doi.org/10.1515/9783110745832-013 
Renaissance may, indeed, be said to depend in a certain sense on the fall of the Byzantine Empire and the immigration of Greek scholars to Italy in the decades before it. These scholars were heirs of the Palaeologan 'Renaissance', which revived learning in the last two centuries of Byzantium and produced scholars like Manuel Chrysolaras (1353-1417), Johannes Argyropoulos (ca. 1415-1487), Constantine Lascaris (1434-1501), or Cardinal Bessarion (1403-1472), who all emigrated to Italy and sparked enthusiastic interest there for Greek Antiquity - including its literature, superstitions, magic, and also science. Some humanists not only used Greek words and phrases in their texts - which was already a common practice among some mediaeval writers - but even penned entire texts in Classical Greek. Despite some fourteenth-century precursors such as Francesco Petrarca (1304-1374) or Coluccio Salutati (1331-1406), Renaissance humanism starts as a large scale phenomenon in the many small fifteenth-century Italian republics and was fuelled by the Greek émigrés. The patronage of the arts by Cosimo de' Medici (1389-1464) in Florence was especially important. ${ }^{5}$ Among other things, he sponsored a Platonic academy led by Marsilio Ficino (1433-1499; see $\$ 4$ below). Beginning in the second half of the fifteenth century, the movement moved across the Alps - early on it arrived in Vienna ${ }^{6}$ - and took roots there in the sixteenth century, especially in Germany and the Netherlands. Cardinal Nicolaus Cusanus (1401-1464) was one of the early adopters; but, despite hailing from Kues (near Luxembourg), he characteristically spent most of his later life south of the Alps. This chapter begins with Renaissance humanism's approach to Latin (§2), then the most important currents of thought are introduced: hermetic neoPlatonism (§3), magia naturalis (§4), and mathematical theology (§5), leading to 'universal science' (§6). The next chapter treats the Scientific Revolution, which can be seen as a synthesis of the Aristotelianism discussed in the previous chapter and the Renaissance currents discussed here.

§2 Already in the later Middle Ages, people who practised good Latin tended to have studied at universities, ${ }^{7}$ in contrast to the earlier Middle Ages, when basic Latin training was usually acquired at ecclesiastical grammar schools. Over the centuries it would seem that - although slowly and far from linearly - proficiency in Latin retreated to ever higher intellectual strata of society, which can be viewed in connection with the emergence of vernacular languages that drifted further and further from Latin, gradually replacing Latin in more and more facets of

5 On which see Hankins (1990).

6 Overfield (1984: 102-103).

7 See Korenjak (2016: 15). 
life, and, finally, precipitating the end of Latin's predominance altogether (see chap. 14 below). Renaissance humanists were not content with university Latin and studied classical rhetoric; they became especially critical of the twelfth-century way of translating verbatim from Greek, which hurt Latin syntax and according to them produced obscuritas. Thus, the Renaissance translator Argyropoulos writes in his Praefatio in librum Phisicorum (Venetiis, 1496 edition), fol. 3v, about his new translation:

invenies, certo scio, faciliores nunc cognitu sententias omnes eius quas perobscuras olim interpretandi modus ille rudis reddebat.

'you will, I do not doubt it, find all his [Aristotle's] thoughts, which that uncultivated way of translating rendered so obscurely in the past, to be of easier understanding.'

Some humanists even wrote treatises on how to translate from Greek. Leonardo Bruni, De interpretatione, ${ }^{8}$ believed that Aristotle wrote in excellent Greek style and had been abused by mediaeval Latin translators. ${ }^{9}$ The discussion of how to translate remained very much alive in the centuries to come. In 1531, Juan Luis Vives reached the other extreme, accusing Aristotle himself of obscuritas, worsened by the translators who 'did not leave it Greek and did not make it Latin', and by scholasticism (De disciplinis, ed. Vigliano, pp. 77-78):

Sed ut Aristotelis obscuritas multum nocuit artibus, sic horum in Aristotelem interpretationes
artes omnes peruerterunt: non potuerunt recte Aristotelem exponere, et haec ipsa difficultas te-
meritatem atque impudentiam exacuebat, ut tanto magis auderet quisque pro interpretamento
adferre quicquid in mentem uenisset, quo minus refelli ac confutari posset inter tantas tene-
bras: et (quemadmodum uulgo dicunt) perturbatus amnis quaestui erat piscantibus: [...] Ver-
sus est male ab imperitis, qui dum in latinum transferunt, nec latinum fecerunt nec reliquerunt
graecum; [...] tractus ab expositore quo nunquam se Aristoteles uenturum potuit suspicari. Vt
iam etiam uulgo inter eos non omnino, ut solent, inscite - Aristoteles dicatur habere nasum cer-
eum, quem quilibet quo uelit flectat pro libito.
'But as much as Aristotle's obscurity damaged the arts a lot, so the interpretations of Aristot-
le by these men perverted all arts: they could not expound Aristotle correctly, and this diffi-
culty aggravated their rashness and impudence, so much so that the more anybody dared to
bring forward whatever he had in mind as interpretation, the less he could be disproved or

8 [L]ibros in greco plenos elegantie, plenos suavitatis, plenos inestimabilis cuiusdam decoris ('In Greek the books are full of elegance, full of subtlety, full of a certain invaluable grace'; §2, ed. Viti, p. 74). Viti's edition also prints Bruni's interesting forewords; Kuhlmann (2002) re-evaluates Bruni's new approach.

9 In fact, the works of Aristotle we possess today were rather terse lecture notes; his works meant for wider circulation are, unfortunately, lost. On this topic in general, see Pym (1998). 
refuted within so much darkness. As people say: troubled rivers bring gain to fishermen. ${ }^{10}$ [...] He was translated badly by inexperienced men, who while transferring the content into Latin, did not make it Latin but did not leave it Greek either. [...] Aristotle is drawn by the interpreter where he could never have expected to end up, so much so that Aristotle was publicly said among them [the scholastics] in a not at all ignorant way (as is otherwise their wont) to have a waxen nose that he turns whither he will., ${ }^{11}$

Although there is no doubt that some late scholastic authors wrote complicated treatises with little actual content in what the humanists must have perceived as horrible Latin, it is on the other hand just as easy to hide a lack of understanding under a veil of classicist rhetoric. As in so many things humanist, Francesco Petrarca led the way. Trying to prove that Plato is to be preferred over Aristotle, he already inveighed against insanum et clamosum scolasticorum vulgus ('the insane and noisy rabble of the scholastics'). ${ }^{12}$ Petrarch preferred a rhetorical Wissenschaftsmodell to the then usual scholastic one (Kessler 1978: 198). In other words, he goes back to the classical Roman lack of interest in science in favour of oratory. A typical humanist rant against scholastic language and thought can be found in Lorenzo Valla's Repastinatio dialecticae et philosophiae. Among many other things, Valla claims that the suffix -tas is abused by scholastics: (4, ed. Zippel, p. 30):

Nulla nomina in 'itas' descendere a substantivis sed ab adiectivis, nec his omnibus.

Quid, quod ab isto 'ens' faciunt 'entitas' (ut de hac quoque materia nunc disputem) qualia multa alia, ut a 'quid' 'quiditas', a 'per se' 'perseitas', ab 'hecce' 'hecceitas' et cetera, e barbarie quodam gurgustio prolata? Nam primum hec ab Aristotele non traduntur, deinde a substantivis deduci nequeunt: 'ens' autem et 'quid' substantiva sunt; postremo nec ab omnibus adiectivis, nisi ab iis que exeunt in 'us', que sunt secunde declinationis (quanquam nec ista omnia), aut in 'er' eiusdem declinationis, et que in 'is' tertie, et in quasdam alias litteras, non omnes tamen.

'That no nouns in -itas can be formed from nouns, but only from adjectives and not even from all of them.

Why, that they [the scholastics] derive entitas from the word ens - let me now enter upon this topic too - as well as many other cases such as quiditas from quid, perseitas from per se, haecceitas from haecce, and so on, acquired from some barbarian hovel. For, firstly Aristotle

10 This saying is not found in Walther (1963-1986). The idea seems to be that fish are more easily caught in the turbulent waters.

11 Vives attacked the Paris scholastics of his own day strongly in his In pseudodialecticos (ed. Fantazzi). More on Valla's, Vives's, and other prominent humanists' attacks against Aristotle and his followers in Rummel (1995: 153-192).

12 De sui ipsius et multorum ignorantia 4, ed. Buck, p. 112. Kessler (1978) evaluated Petrarch as a historian and philologist and reached mixed conclusions. Petrarch had no interest whatsoever for natural sciences and has to be seen mostly in a rhetorical, humanist context. 
does not use these terms, then they cannot be formed from nouns [in "proper" Latin], finally they cannot even be formed from all adjectives but only from those in - us (second declension) - although not even of all of them - and in -er (same declension), and those in -is (third declension), and some others, but not all.'

Later (5, p. 36) he claims that fine scholastic terminology is meaningless:

Inter 'essentiam' et 'esse' nihil interesse et item in ceteris, ut inter 'voluntatem' et ipsum 'velle'. 'That there is no difference between essentia and esse, and similarly in other cases such as voluntas and velle.'

Both these points overshoot the target: it will have become obvious that a detailed terminology is fundamental for scientific thought, and there are even classical exceptions to his linguistic point (necessitas from necesse, civitas from cives). Nonetheless, such bold claims helped to make people more aware of their language, and considering to what parts of speech suffixes can be appended is an important linguistic achievement. Among authors like Valla, the prejudice of a dark middle age between the Roman orators and themselves began to be felt. For instance, Valla saw Isidore as indoctorum arrogantissimus ('the most arrogant of the uneducated'). ${ }^{13}$ Needless to say, these humanist polemicists did not make any significant scientific discoveries themselves - even less so than their much-admired Cicero (see chap. 8 §7). It was from these people that the idea of an unadulterated Latinity, allowing the use exclusively of what can be shown to be extant in Cicero, began; pupils of the humanist gymnasium had to put up with it as late as the twentieth century. ${ }^{14}$ But some early humanists, such as Angelo Poliziano (14541494), already saw that a complete emulation of Cicero, prohibiting all words and expressions not found in him, was not a good idea. He points out in a letter to Paulo Cortesi (ed. Garin, p. 902):

Mihi certe quicumque tantum componunt ex imitatione, similes esse vel psittaco vel picae videntur, proferentibus, quae non intelligunt. Nihil ibi verum, nihil solidum, nihil efficax. Non exprimis, inquit aliquis, Ciceronem. Quid tum? non enim sum Cicero; me tamen, ut opinor, exprimo.

'It seems to me that those who compose only through imitating are similar to parrots or magpies: they express what they do not understand. There is nothing true, nothing solid, nothing powerful in them. One says: "you do not express yourself like Cicero." And so? I am not Cicero; it seems to me that I should express myself as myself!'

13 Elegantiae II, ed. Garin, p. 602.

14 We will review some 'antibarbarus' literature from later times in chap. 14 §11 below. 
New grammars (late mediaeval modist speculative grammar theory was among the main targets of the humanists) ${ }^{15}$ and new dictionaries were necessary to teach the new language. The most successful, and at the same time an unusual and extreme one, was Nicolaus Perotti's Cornucopiae (1506). It started as a commentary on Martial but grew into a full dictionary of Classical Latin. A list at the beginning tells the reader where to find which word in the big tome. Thus, scientia is found in column 1019, part D, while commenting on Martial's Epigramma I.3 (modern numbering) Argiletanas mavis habitare tabernas:

\begin{abstract}
Nescio autem ex ne \& scio componitur. Scire autem proprie est rem ratione \& per causam cognoscere a quo Scientia dicitur rerum quae sunt inmutabili ratione comprehensio. Cicero Ars enim eorum est quae sciuntur. Oratoris autem omnis actio opinionibus non scientia continetur. ${ }^{16}$ Ponitur autem frequenter scio pro cognosco intelligo a quo fit Scisco inchoatiuum: \& participium sciens: \& Scienter aduerbium.

'The word nescio is composed of ne and scio. Scire properly is to know something rationally and through its causes, which is why scientia is said to be the understanding by reason of things that are unchangeable. Cicero says: for art is of things that are known. But all actions of an orator depend on [his audience's] opinion, not on knowledge [scientia]. Scio is also often used instead of cognosco or intelligo; thus an inchoative form scisco is formed, besides a participle sciens and an adverb scienter.'
\end{abstract}

The examples and usages are exclusively classical: for instance, under oratio the author does not mention that the word also means 'prayer' in Christian Latin. ${ }^{17}$ The sixteenth and seventeenth centuries will see more balanced dictionaries, beginning with Calepinus (used in chap. $2 \S 5$ above).

Humanist Latin by no means supplanted scholastic Latin in the centuries following the humanist Renaissance. After sometimes rather bilious strife between humanist poets and scholastic scholars, ${ }^{18}$ a kind of demarcation of competences largely prevailed: the former in rhetoric, speeches, poetry, and the like; the latter in universities and science. ${ }^{19}$ The two registers, humanist and scholastic, of-

15 See Overfield (1984: 75-86).

16 Quotation from Cicero, De oratore II.7(30), ed. Kumaniecki, p. 115.

17 Further on the Cornucopiae: Furno (1995).

18 Some examples are studied by Overfield (1984: 120-142), e.g. 'many Germans resented the smug sense of superiority exuded by the Italians' (141).

19 Already Olschki pointed out: 'Es ist klar, dass man mit dem relativ beschränkten Sprach- und Stilschatz Ciceros nicht den ungeheuren Wissensschatz beherrschen konnte, den die Gelehrten der Renaissance aus den entferntesten Gebieten der Kultur- und Naturgeschichte zusammengetragen hatten' ('It is clear that with Cicero's relatively limited vocabulary and style, it was not possible to master the immense wealth of knowledge that the scholars of the Renaissance had gathered from the most remote areas of cultural and natural history'; 1922: 71). The same assessment is made by Stotz (1996-2004: I, §67.11 = vol. 1, pp. 166-167) and Korenjak (2016: 11). 
ten coexisted much more closely than one tends to realise, as in Pico della Mirandola's (1463-1494) famous Oratio de dignitate hominis, written in very humanistic Latin in 1486 and intended as an introduction to his much longer catalogue of nine hundred theses in normal 'scholastic' Latin (Conclusiones nongentae). ${ }^{20}$ Pico may have been more aware of the relativity of such language registers due to his familiarity with Greek and Hebrew. In a letter to Ermolao Barbaro, he points out (ed. Garin, p. 818):

quid prohibet hosce philosophos, quos nuncupatis barbaros, conspirasse in unam dicendi normam, apud eos non secus sanctam ac habeatur apud vos romana?

'what forbids those philosophers whom you call barbarians having conspired to use a single linguistic norm as sacred to them as to you the Roman tongue?'

Pico goes on to quote the antique 'noble savage', the Scythian Anacharsis:

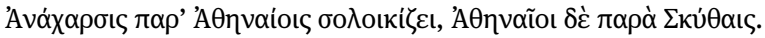

'Anacharsis speaks badly for the Athenians, the Athenians for the Scythians.'

He concludes (pp. 820-822):

Scribat Lucretius de natura, de Deo, de providentia, scribat de eisdem ex nostris quispiam, scribat Ioannes Scotus et quidem carmine ut sit ineptior. Dicet Lucretius rerum principia atomos et vacuum, Deum corporeum, rerum nostrarum inscium, temere omnia fortuito occursu corpusculorum ferri, sed haec latine dicet eleganter. Dicet Ioannes quae natura constant, sua materia specieque constitui, esse Deum separatam mentem, cognoscentem omnia, omnibus consulentem. [...] At dicet insulse, ruditer, non latinis verbis. Quaeso, quis in dubium revocet, uter poeta melior, uter philosophus?

'Let Lucretius write about nature, God, Providence; let someone of ours [a Christian] write about the same things, let us say Duns Scotus, and he is not so poetically minded. Lucretius will say that atoms and emptiness are the principles of things, God corporeal and not caring about our matters, that everything happens by chance collision of particles, but he says it in elegant Latin. Duns will say that what exists in nature is made up of matter and form, that God is a mind separate from it, who knows all, takes counsel about everything. [...] But he says it in a tasteless, rude manner, in words that are not Latin. I ask: who would doubt who is the better poet, who the better philosopher?'

Pico could say such things and get away with them among humanists, because he penned them in very rhetorical humanist Latin. In general, in later times the two approaches have to be seen rather as two different registers adapted for different uses than as exclusive types of 'good' and 'bad' Latin. Thus, although curricula shifted toward a greater importance of studia humaniora at German universities in

20 Editions: Garin; Biondi. More on Pico’s ‘double tongue’ in Moss (2003: 67-70). 
the later 1510s, scientific study, its sources and goals, hardly changed. ${ }^{21}$ Humanism was a rhetorical, not a scientific movement. Indeed, Thorndike (1943) draws very negative conclusions about humanism's impact on science: he sees humanists as uniform and backward with their wish to imitate Roman classical times. Science was still predominantly done at Aristotelian universities, such as Padua (especially the natural sciences). Private academies and societies would only become important in science in the seventeenth century. ${ }^{22}$ As Eugenio Garin puts it: 'Aristotelica, dunque, rimaneva, almeno per buona parte l'indagine scientifica, l'ossatura del sapere' ('Scientific investigation, therefore, remained Aristotelian, at least for the most part, the skeleton of knowledge'; 2009: 35).

In general, Mediaeval Latin is divided from Neo-Latin precisely on the grounds of a more classicist approach to language from the fifteenth century onward. In poetry, for instance, the difference is often striking. In contrast, the extent to which the humanist movement influenced scientific writing seems to depend quite a lot on the science in question. In less 'humanistic' sciences (so to speak) such as the natural sciences or medicine (see chap. 21 below), clear humanist linguistic influence is rare; ${ }^{23}$ in some of them, a change of style around the sixteenth century can be observed, although not toward a humanist style but toward a Euclidean axiomatic approach, for example in mathematics and physics, but also in Spinoza's ethics. ${ }^{24}$ In other sciences, a more pretentious, rhetorical style did come to be expected, for instance in philology or literary studies, indeed in the traditional human sciences. Philosophical scholasticism may be said to have become more conscious of its possible fallacies as a result of the attacks of the humanists. It was to remain important and was to produce a new flowering in Spanish neo-scholasticism (discussed in chap. $11 \S 7$ above), which had, among other things, important contributions to make to the formation of international law. Incidentally, humanism and the human sciences bear a similar name by historical accident only, ${ }^{25}$ but it has recently been pointed out that the humanist Poliziano can be seen as the ori-

21 See Overfield (1984: 298-299).

22 On these see Biagioli (2002).

23 For some notes on the language of medicine, including exceptions to the above statement, especially Vesalius, see chap. 21 below. The interest in antique science that was significant in many fields would hardly seem typically humanist; it was already common among many mediaeval scholars. In law, for instance, authors such as Hugo Donellus (1527-1591) speak of 'legal humanism'. Their main point was to go back to the antique texts, disregarding mediaeval commentators.

24 Rummel (1995: 195) rightly speaks of the 'third option' besides scholasticism and humanism. 25 Compare German Humanismus vs Geisteswissenschaft. Indeed, the former's meaning is a recent acquisition, coined by Niethammer (1808). 
ginator of a special kind of humanist science. ${ }^{26}$ He proposes in his Panepistemon a new classification of the sciences into speculativa (approximately natural sciences), practica (approximately artes mechanicae), and rationalis (encompassing historia ad fidem, distinguished from historia fabulosa, which is not scientific; dialectic, rhetoric, and poetry). This adds the scientific study of history to the usual trivium, but we have seen (chap. $9 \$ 1$ ) that a similar approach can already be traced in Augustine.

Sarton (1929: 80) had a point when he called Renaissance humanists 'sophists' with few exceptions. But even if humanism as a rhetorical movement had little impact on science, the renewed interest in Antiquity also led some humanists to seek out new ways in scientific inquiry. It will become apparent that the Renaissance Platonist movement did provide some new methodological impulses to science.

\$3 The Renaissance had a clear preference for Plato over Aristotle. Renaissance scholars meant to reintroduce what was lost from Antiquity, such as Platonism, but this grew into something quite new. In the case of Renaissance Platonism, antique neo-Platonism grew into hermetic neo-Platonism with a penchant toward pantheism and a special interest in magic. ${ }^{27}$ The priest Marsilio Ficino (1433-1499) translated all the extant Platonic dialogues into Latin for the first time at Lorenzo de' Medici's Platonic academy in Florence; he also translated many neo-Platonic works, such as Plotinus' Enneads and the Corpus Hermeticum. ${ }^{28}$ He delved so far into neo-Platonist occultism that he had to write an Apologia justifying his interests. ${ }^{29}$ The Corpus Hermeticum in particular came to enjoy huge prestige as prisca sapientia (a term dear to Ficino) and an Egyptian precursor of ancient Greek learning, especially at Italian Renaissance academies; this lasted at least until the philologist Isaac Casaubon was able to date this 'ancient' wisdom to Late Antiquity in 1614. The Corpus Hermeticum's main theme is the unity of all things that the hermeticist should find, especially his own with God. The result is quite far from science as we understand it; Sarton (1929: 79) would speak of a 'superficial mixture of ideas too vague to be of real value'. Neo-Platonism, which had already been largely incorporated into the thinking of the Church Fathers in a 'purified' form (i.e. minus its all too 'pagan' and 'superstitious' constituents) and thus heavily influenced the Middle Ages and scholasticism, returned now in its unadulterated late antique form - including the traits that the Church

26 Edelheit (2015).

27 The seminal study on this is Yates (1964).

28 Greek text ed. Nock \& Festugière.

29 Details in Thorndike (1923-1958: 4:562). 
Fathers had found unacceptable. Interestingly, these were mostly non-scientific ones, as we would say today (using e.g. the criteria in part 1): theurgy, demonology, magic, secrecy (lack of sharing results with the uninitiated), or number mysticism. Thus, Renaissance science with its turn to 'Platonism' (through neo-Platonism) was rather a step back in terms of scientific testability and transparency. We can quote a later, but very characteristic author: Giordano Bruno. He is notable for his philosophical poems (Francofurti, 1591) written in clear imitation of Lucretius. De monade, numero et figura studies the first ten numbers as metaphysical entities and their magical and philosophical meanings in very obscure and often purposefully ambiguous language, of which the following sentence describing the circle can serve as an example (De monade, numero et figura 2, lines 4-14, ed. Fiorentino, vol. 1.2, p. 335):

Hoc de fonte fluunt primoque parente, figurae

Clarandaeque forum ipsius iustumque tribunal

Conquirunt, facie inque sua spectantur adauctae,

In faciemque suam degliscunt omnia tandem:

Illius ut crescit surgens in imagine horizon

Amplius a nostris se quando sensibus effert,

Illius ut formam capiunt attrita recessu

Corpora ad obtutum, quando momenta perire

Cuspidis expertum est, laterum discrimina vultus

Amittunt rerum, in speciem cita principiorum,

Quo amplius in nihilum ad oculos solvenda fatiscunt.

'From this source and first ancestor [i.e. the circle] they [i.e. mathematical shapes] flow forth, the figures that are to be explained search it out as its marketplace and its just tribunal. When increased, they are seen in its surface; toward its surface they all un-grow ${ }^{30}$ at length. The horizon grows in its image as it widens further when it removes itself from our senses. Apparently, worn-off bodies take something like its form in departure, when it experienced the perishing of the thrust of the spear, ${ }^{31}$ and the looks of things lose the difference of their sides, then cite them to the realm of ideas where visible things decay the more into nothingness.'

The poems are in general very hard to understand: often it is hard to tell whether the author is speaking about geometric constructions or about metaphysical entities: in fact, it would seem that he usually intends both. The vocabulary is relatively normal; the obscurity comes rather from the often ambiguous syntactic nexuses and the precise meaning of the often poetically circumscribed terms. Secrecy was certainly intended. Bruno also wrote more accessible works in Italian.

30 Deglisco is a very uncommon word, not found in dictionaries.

31 Von Samsonow et al. (1991: 226-227) believe this to be a chiffre for a geometric method. 
\$4 One way in which the new Renaissance outlook did profit science was through its stress on experimentalism, which went under the heading of magia naturalis. ${ }^{32}$ Arabic sources already differentiated between 'natural' and demonic magic, ${ }^{33}$ only the first of which is licit. The Latins took this over; the Latin term is used as generally known since at least William of Auvergne (d. 1249). ${ }^{34}$ Giambattista della Porta's (1535?-1615) huge encyclopaedia, Magia naturalis (1558), shows the wide range of phenomena that could be subsumed under this heading: a lot of medicine, magnetism, poisons, witches, invisible writing, and much more. This natural magic is eulogised by Cornelius Agrippa of Nettesheim (1486-1535) as (De occulta philosophia I.2, ed. Compagni, p. 86):

Magica facultas, potestatis plurimae compos, altissimis plena mysteriis, profundissimam rerum secretissimarum contemplationem, naturam, potentiam, qualitatem, substantiam et virtutem totiusque naturae cognitionem complectitur et quomodo res inter se differunt et quomodo conveniunt nos instruit, hinc mirabiles effectus suos producens, uniendo virtutes rerum per applicationem earum ad invicem et ad sua passa congruentia, inferiora superiorum dotibus ac virtutibus passim copulans atque maritans: haec perfectissima summaque scientia, haec altior sanctiorque philosophia, haec denique totius nobilissimae philosophiae absoluta consummatio.

'The magic faculty, compounded of most powers, full of highest mysteries, comprises the most profound contemplation of secret things, nature, potency, quality, substance and virtue, and the knowledge of all nature. It instructs us how things differ among one another and how they come together in order to produce their miraculous effects by unifying the virtues of things by applying them to one another and to their congruent passive sides, by here and there coupling and marrying the lower things to the gifts and virtues of the upper [heavenly]. This is the most perfect and highest science, this is the higher and holier philosophy, this, finally, is the absolute consummation of the most noble philosophy.'

This passage is quite typical in many ways: the complicated, hymnic language, the emphasis on mystery but also the lack of interest in scientific step-by-step explanations. Other authors were less cautious and did study illicit, demonic magic as well. Authors who engaged in it often fared badly: Giordano Bruno was burned at the stake for heresy in 1600; John Dee (1527-1608/1609) had to face a life of hardship. Not such extreme adepts, but rather experimentally minded scientists who coupled magical 'virtues' and higher and lower influences, were to have last-

32 On which see Zambelli (2007). The form magica is also used with the same meaning.

33 The latter is forbidden as sorcery in Islam (Quran, Sura 2.102). The Arabic roots of magia naturalis and their effects on the Latin world merit a profounder study than Saif (2015).

34 See Thorndike (1923-1958: 3:346), quoting De universo I.1.43, 1674 edition, vol. 1, p. 648: in ea parte naturalis scientiae, quae vocatur magica naturalis ('in that part of natural science that is called natural magic'). 
ing influence. Indeed, one of the main points of Thorndike's magnum opus (19231958) was to show the kinship between such magic and the rise of experimental science; a point that has today become a commonplace. In this split of magia into magic proper (magia ritualis vel daemonica) and magia naturalis, which becomes a part of scientia, the formative rôle of the Church should not be overlooked: it was the Church that made magia refrain from accepting demonic (unscientific) powers as 'mechanisms' - the same sound guiding influence it had already exercised in Late Antiquity on neo-Platonism. On the other hand, licit magia naturalis's experimental and mechanistic tendencies greatly benefited the development of natural experimental science.

Apart from authors on magia naturalis, a new type of technician and practical scientist becomes more common in the fourteenth and fifteenth century; for the first time, some of these practitioners did not hail from Latinate society. Leonardo da Vinci (1452-1519), for instance, was self-taught in Latin, and his theoretical works did not find as great a resonance as his famous art. Others are still understudied, such as the Venetian engineer Giovanni Fontana (ca. 1395-ca. 1455); ${ }^{35}$ his works on war machines, mnemotechnics, and clocks still exist only in manuscript form, but a work of his on machines has recently been edited (Liber instrumentorum iconographicus, ed. Kranz). He also wrote an encyclopaedia of natural philosophy that was printed in 1544. Niccolò Tartaglia wrote a treatise on ballistics in Italian (La nova scientia, 1537). Natural scientists of the following period were to profit from their new devices and discoveries. Galileo (chap. 13 §4) was to fit well into this type of practically minded scientist and engineer.

A brief look at the language used by two important authors will now be taken. Hieronymus Cardanus (1501-1576) stood between different worlds: he was a scientist in the new spirit (see next chapter) and was interested in natural magic, Lullian combinatorics, and new scientific devices; his style is sometimes quite in the vein of the humanism of his time, but his many compendious works look rather scholastic in nature. There are some 130 printed works of his; they treat problems in mathematics, physics, medicine, astrology, philosophy, religion, and music. His main contributions were mathematical and medical. His mathematical main work is called the Ars magna (Norimbergae, 1545), echoing the title of Lullus' main work (see $\S 5$ below). This work presents for the first time general solutions to polynomial equations of degrees 3 and 4, although these formulas were not discovered by Cardano himself. His large, encyclopaedic compendium De subtilitate treats 'subtlety' in twenty-one books (1st ed., Norimbergae, 1551). He aims to ex-

35 See Clagett (1976) on his life and works. 
plain difficult and refined things in nature, man, the senses, the soul, science, demonology, theology; the epilogue adds (Basileae, 1554 edition, p. 560): quaedam ob raritatem, quaedam ob difficultatem adiecimus ('we added some things because of their rarity, some because of their difficulty'). His goal is explained thus (I.1, ed. Nenci, p. 53): ${ }^{36}$

Propositum nostri negocii in hoc opere est, de subtilitate tractare. Est autem subtilitas ratio quaedam, qua sensibilia a sensibus, intelligibilia ab intellectu, difficile comprehenduntur. [...] Idque solum apertum et facile videri potest, quod in unaquaque disciplina est obscurissimum. [...] Cum enim scribentes in quatuor laborent generibus, rerum obscuritate, incertorum dubitatione, causarum inventione, rectaque earum explicatione, omnia haec hoc in libro cumulatius habentur. [...] Quaedam etiam cum desierint, aut nuper sint inventa, nominibus aut carent, aut nomina rebus ipsis. Porro nomina invenire novis rebus, et senescente lingua, difficillimum est. [...] Constat ergo subtilitas in tribus, substantiis, accidentibus, ac repraesentationibus.

'The purpose of our work is to treat "subtlety". Subtlety is an approach by which sensible things are understood by the senses with difficulty, intelligible things by the intellect. [...] And it alone is capable of making openly and easily visible what is most difficult in each discipline. [...] Now, as those who write struggle with four problems: obscurity of things, doubting of uncertain things, finding of causes, their correct explanation: all of these are contained in this one book together. [...] Some things that are missing were either recently discovered, or lack names, or the names lack things. But it is very hard to invent names for new things in a language that is growing old. [...] Thus, "subtlety" consists of three spheres: substances, accidents, and representations.'

The author thus believes that explaining difficult things in all sciences in one book will help to make them plainer. He is also an early scientific voice perceiving Latin as growing too old for scientific use. The book contains many geometric figures and some sketches of 'subtle' devices. ${ }^{37}$ Julius Caesar Scaliger (1484-1558) wrote a 1,128-page 'review' (Exoticarum, first published 1557) of the work, disagreeing with some things and elaborating on others, which shows a spirit of scientific discussion.

\$5 A related undercurrent with a long past but becoming influential only during Renaissance times is mathematical theology of a 'Pythagorean' kind. Its kinship to hermeticism and neo-Platonism is apparent - Proclus had already tried to mathematicise theology in his Elementa theologica - but its line of development leads elsewhere. Authors of this kind had a tendency to coin unusual vocabulary

36 This is a modern edition of books I-VII; see also the edition project at http://www.cardano. unimi.it.

37 The approach to natural science is analysed by Schütze (2000). 
for their unusual thoughts. In fact, this - as we might call it - 'lower' neo-Platonism had already reached some individuals before Ficino's translations, presumably through Arabic intermediaries or direct contact. An influx of Christianised Qabalistics already arose in some authors in the thirteenth century. This kind of thought typically sought correspondences or 'sympathies' between different levels of reality. Examples are the Byzantine demonologist Michael Psellos (1017/ 1018-ca. 1078), who had direct access to the Greek sources, the eschatologist Joachim of Fiore (ca. 1135-1202) in his Liber figurarum (ed. Tonelli), ${ }^{38}$ the Catalan missionary Raimundus Lullus (ca. 1232-1316), or alchemists such as John of Rupescissa (1310-ca. 1370).

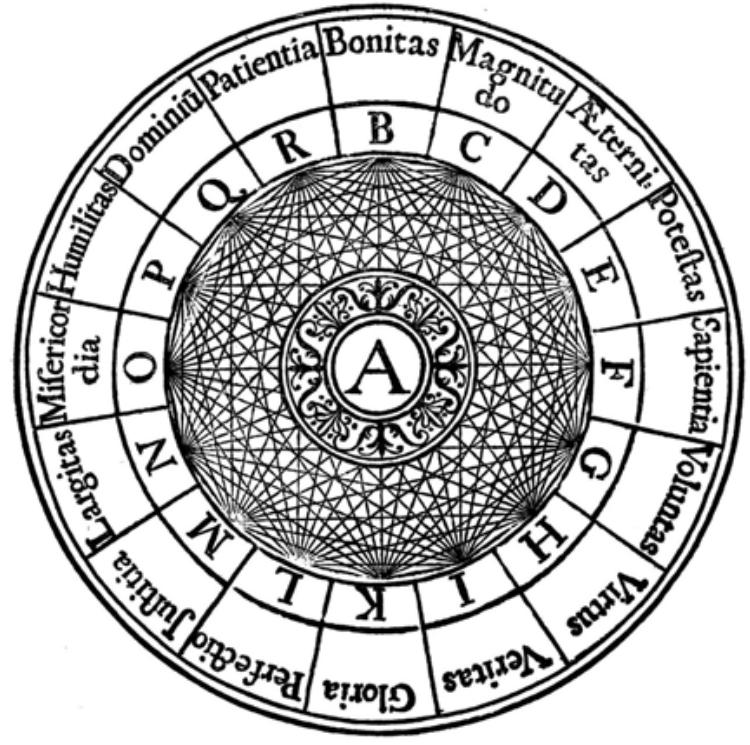

Fig. 20: Figura A from Lull's Art (Moguntina edition, vol. 1, after p. 432).

Lullus worked on his ars lulliana for much of his life, a combinatoric system that he believed would be able to reform the sciences, especially the science of theology, and become their common foundation. In various forms of movable figures with epithets of God (one of them is depicted in fig. 20), he believed he was able to form the basis of a 'scientific' theology that would prove the Trinity and the Incar-

38 On this topic, see Guerrini (2016). 
nation of Christ to non-Christians. His system seems to have been inspired by Qabalah and mystic Islam. Lull's ars is apparently meant to be able to classify all strata of being, but it does not work purely mechanically; ${ }^{39}$ the name ars (not scientia) may have been chosen in order to stress its practical aspects of bringing the artista toward God. Leibniz was to be impressed by this art and would develop it further, although in a mathematical not a theological way, into the science of combinatorics. Its details remain - despite repeated new attempts to explain it by its author - rather obscure. It would seem that the obvious closeness of mystic currents in all three Abrahamitic religions that Lullus had apparently noted stems from their common neo-Platonist ingredients. They also form the basis of Lullus' system. This system would fail to qualify as scientific according to our criteria, but this important precursor of Renaissance Platonism used a very special language that is worth noting in this context. He coined terms that might be called hyperscholasticisms, such as unificentia, bonificentia, aeternificentia, ${ }^{40}$ and constructed a fully fledged system of derivations in groups of divine attributes. Thus, bonitas becomes the set of bonificativus, bonificabilis, and bonificare: ${ }^{41}$ that through which bonitas happens, that which can receive it, and the act of bestowing it. Thus, the typically scholastic suffixes -ivus and -bilis can be used freely to build up a linguistic system mirroring Lullus' conception of how things are. This may be the boldest mediaeval attempt at Latin language engineering. The following example illustrates both his language and his main idea (Ars generalis ultima 1, ed. Madre, $R O L$ 14, pp. 5-6):

Quoniam intellectus humanus est ualde plus in opinione, quam in scientia constitutus, ex eo quia quaelibet scientia habet sua principia propria, et diuersa a principiis aliarum scientiarum, idcirco requirit et appetit intellectus, quod sit una scientia generalis ad omnes scientias. Et hoc cum suis principiis generalibus, in quibus principia aliarum scientiarum particularium sint implicita et contenta, sicut particulare in uniuersali. Ratio huius est, ut cum ipsis principiis alia principia subalternata sint et ordinata, et etiam regulata, ut intellectus in ipsis scientiis quiescat per uerum intelligere, et ab opinionibus erroneis sit remotus et prolongatus. Per hanc quidem scientiam possunt aliae scientiae faciliter acquiri.

'As the human intellect is much more grounded in opinion than in science, due to the fact that every science has its own principles, differing from those of the other sciences, therefore the intellect requires and desires one science general to all other sciences. And this science ought to have its own general principles, in whose principles those of the other particular sciences be implicit and contained, as particulars are contained in universals. The reason for

39 He says: absque ratione artista non potest bene uti ista arte ('without reason the artist cannot use this art well'; Ars generalis ultima 13, ed. Madre, ROL 14, p. 524). Platzek (1962) is a good introduction to this difficult author.

40 Liber de scientia perfecta dist. 1, ed. Stöhr, ROL 1, vol. 1, pp. 224-225.

41 Ars generalis ultima IV.3, ed. Madre, ROL 14, p. 31. 
this is that by these principles others will be subordinate to them and be put in line and also be ruled, so that the intellect will find peace in these sciences understanding the truth and that it can be removed and separated from wrong opinions. By means of this [general] science the other sciences can then easily be acquired.'

It may be important in this context that Lullus was a layman, an outsider among university people, who came to scholarly writing only after undergoing a mystical experience. What Lullus may have groped his way toward is the idea that formalisation (in the form of mathematics as well as language engineering) can indeed be a general foundation for all sciences. There was serious opposition to Lullus' innovations in university circles, and even the Inquisition took an interest in him.

Another author in this tradition is Cardinal Nicolaus Cusanus (14011464), who had read Lullus and also coined unusual words, although he did not create a system from them. Often they are also attempts to name the unnameable (God), such as his possest (of God being the coincidentia of actus and potentia, posse and esse), or his referring to God as tricausalis. A matter of questionable Greek is his trialogus, a dialogue between three people. ${ }^{42}$ Other authors who continued to spin such ideas further include magicians such as Giordano Bruno and John Dee.

\$6 Similar hermeticist neo-Platonist currents ${ }^{43}$ can still pop up among scientific disciplines today - as in Rudolf Steiner's (1861-1925) 'spiritual science', Carl Gustav Jung's (1875-1961) depth psychology, or Fritjof Capra's (1939-) Taoist Physics - usually controversial and often spurned by scientists in the fields in question. What unites these authors can be described as introspection, mysticism, esotericism, and holistic approaches, all of which have been alien to university scholarship and science, whose methodology stayed largely Aristotelian through the Renaissance and still is so today. ${ }^{44}$ Another point that unites at least some of the authors mentioned is their dabbling or even outright failures in generally acknowledged science: Lullus was convinced that his ars nova could revolutionise all sciences, and Cusanus believed he had squared the circle. ${ }^{45}$ This universalist

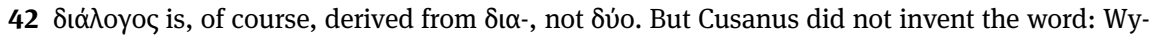
cliffe had already used it as a work title: Trialogus, ed. Lahey; see Werner (1999).

43 An important tool for studying these currents is Hanegraaff (2006).

44 Kullmann $(1974,1998)$ shows the many links between modern science and Aristotelian methods.

45 See Uebinger (1895: esp. 403-414). Regiomontanus, De triangulis, proved that Cusanus' constructions were wrong. 
approach continued to flourish in the age of the Scientific Revolution as a kind of science which tried to produce a synthesis of the Platonic Renaissance science and the 'new' science (treated in the next chapter); among these authors, Kircher believed he had deciphered the Egyptian hieroglyphs. This approach typically made use of the Latin language, of tables and figures and systems of characters and signs of all kinds, though less of mathematical ones. These authors mix 'Wissenschaftlichkeit und stilistische Höhenflüge' ('scientificity and stylistic flights of fancy'; Korenjak 2016: 246). Some among them would become part of the scientific mainstream, such as Copernicus, whose motivation for putting the Sun at the centre of the universe was at least in part a kind of mystical Sun-theology, ${ }^{46}$ or the hermeticist Kepler (on these authors, see chap. 13). ${ }^{47}$

On the whole, the Renaissance movement did change the outlook on many things, but (Thorndike 1923-1958: 4:4)

much of all this was a somewhat superficial phenomenon and not so extensive as it appeared on the surface. The scholastic method was kept up at numerous universities. Medieval Latin and Arabic authors continued to pour from the printing press.

The authors of this mystic-holistic and Platonic 'science' were much less numerous than the countless 'Aristotelians' at the universities since the thirteenth century. They can be arranged in a web of dependencies in a way that the authors from before and during the Scientific Revolution studied in the next chapter could not. This provides a hint to the fact that this Platonic scientific 'underground' movement was of a much more limited scope than the Aristotelian 'mainstream' science, although, of course, the two movements were linked. The authors at the bottom right in figure 21 were, in fact, also important exponents of the Scientific Revolution. Experimentalism and magia naturalis and a new return to Greek natural science were major ingredients in the Scientific Revolution discussed in the next chapter. We might consider having the period of Renaissance science end in AD 1543, the annus mirabilis (Sarton 1929: 86) in which several groundbreaking works for science were published.

46 e.g. the hymnic formulation in De revolutionibus I.10 quoted in chap. $13 \S 4$ below.

47 e.g. Kepler's Harmonices mundi (Lincii, 1619) is of a hermeticist nature. 


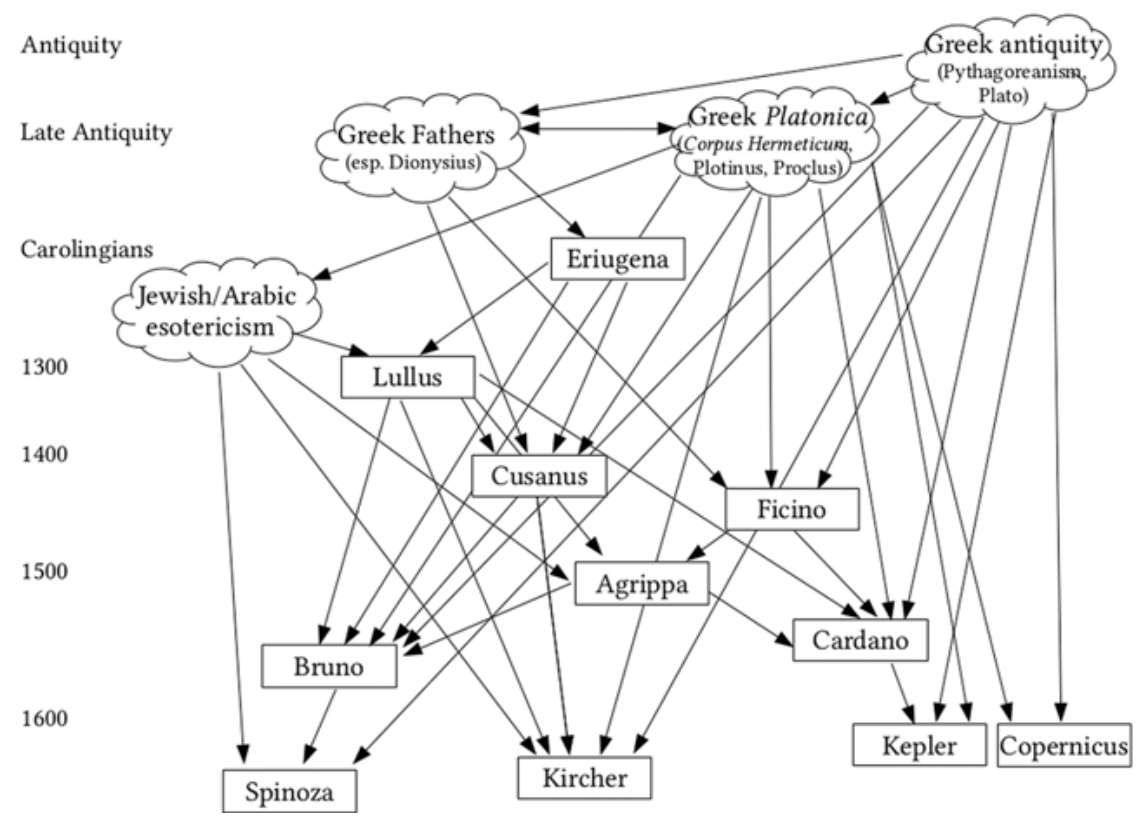

Fig. 21: Tentative web of influences among some important hermetic-Platonist authors.

\section{Relation to criteria for science}

\$7 Despite the Renaissance's importance as a literary movement, it failed to alter the sciences to the same depth. Especially in the natural sciences, universities kept using scholastic methods and language; indeed, it will be seen below (chap. 18) that the language employed changed much less dramatically in the fifteenth century than it had with the advent of scholasticism in the thirteenth. It might be argued that the new forms of Renaissance Platonism stimulated mathematical approaches and magia naturalis experimental ones, thus paving the way for the Scientific Revolution treated in the next chapter. This is true to some extent, but mathematics progressed to its significant advances in the sixteenth century largely in traditional settings; indeed, a chain of important precursors from the twelfth to the fifteenth century can easily be named. ${ }^{48}$ Precursors for the experimental method among the 'magicians' of the pre-humanist centuries can also be found abundantly, as Thorndike's monumental work (1923-1958) shows.

48 The fourteenth-century Oxford calculators were encountered above (chap. 11 §5); for arithmetic, some more texts will be met below (chap. 20 §2). 
While rhetorically minded Renaissance humanism had its influence on some concomitants of science but was not a scientific movement at all, the other current we have described, Platonic Renaissance hermeticism, can be said to have had a systematic method (I) and to have built a coherent system (IV), but it was one that focused too much on the greater patterns only (II) and largely lacked testability (III). It did not 'walk' (as Galen put it). A larger community was certainly active at the Aristotelian universities than at the Renaissance private academies (V). As already stressed, some authors moved in both worlds, some also used both kinds of Latin (humanist and scholastic) for different purposes, and in some authors mathematical formalisation advanced significantly - but these are the very authors usually included in the Scientific Revolution to be studied in the next chapter. Thus, the quotation from Sarton at the beginning of this chapter is largely confirmed: the Renaissance was not so much one of science, but some of its new ideas - especially mathematical and experimental magia naturalis - would still bear fruit in the Scientific Revolution. 